\title{
Structural and magnetic properties of ball milled copper ferrite
}

\author{
Goya, G.F.; Rechenberg, H.R.; Jiang, Jianzhong
}

Published in:

Journal of Applied Physics

Link to article, DOI:

10.1063/1.368109

Publication date:

1998

Document Version

Publisher's PDF, also known as Version of record

Link back to DTU Orbit

Citation (APA):

Goya, G. F., Rechenberg, H. R., \& Jiang, J. (1998). Structural and magnetic properties of ball milled copper ferrite. Journal of Applied Physics, 84(2), 1101-1108. https://doi.org/10.1063/1.368109

\section{General rights}

Copyright and moral rights for the publications made accessible in the public portal are retained by the authors and/or other copyright owners and it is a condition of accessing publications that users recognise and abide by the legal requirements associated with these rights.

- Users may download and print one copy of any publication from the public portal for the purpose of private study or research.

- You may not further distribute the material or use it for any profit-making activity or commercial gain

- You may freely distribute the URL identifying the publication in the public portal

If you believe that this document breaches copyright please contact us providing details, and we will remove access to the work immediately and investigate your claim. 


\title{
Structural and magnetic properties of ball milled copper ferrite
}

\author{
G. F. Goya and H. R. Rechenberg \\ Instituto de Fisica, Universidade de São Paulo, CP 66318, 05315-970 São Paulo SP, Brazil \\ J. Z. Jiang ${ }^{\text {a) }}$ \\ Department of Physics, Building 307, Technical University of Denmark, DK-2800, Lyngby, Denmark
}

(Received 5 December 1997; accepted for publication 10 April 1998)

\begin{abstract}
The structural and magnetic evolution in copper ferrite $\left(\mathrm{CuFe}_{2} \mathrm{O}_{4}\right)$ caused by high-energy ball milling are investigated by $\mathrm{x}$-ray diffraction, Mössbauer spectroscopy, and magnetization measurements. Initially, the milling process reduces the average grain size of $\mathrm{CuFe}_{2} \mathrm{O}_{4}$ to about 6 $\mathrm{nm}$ and induces cation redistribution between $\mathrm{A}$ and $\mathrm{B}$ sites. These nanometer-sized particles show superparamagnetic relaxation effects at room temperature. It is found that the magnetization is not saturated even with an applied field of $9 \mathrm{~T}$, possibly as the result of spin canting in the partially inverted $\mathrm{CuFe}_{2} \mathrm{O}_{4}$. The canted spin configuration is also suggested by the observed reduction in magnetization of particles in the blocked state. Upon increasing the milling time, nanometer-sized $\mathrm{CuFe}_{2} \mathrm{O}_{4}$ particles decompose, forming $\alpha-\mathrm{Fe}_{2} \mathrm{O}_{3}$ and other phases, causing a further decrease of magnetization. After a milling time of $98 \mathrm{~h}, \alpha-\mathrm{Fe}_{2} \mathrm{O}_{3}$ is reduced to $\mathrm{Fe}_{3} \mathrm{O}_{4}$, and magnetization increases accordingly to the higher saturation magnetization value of magnetite. Three sequential processes during high-energy ball milling are established: (a) the synthesis of partially inverted $\mathrm{CuFe}_{2} \mathrm{O}_{4}$ particles with a noncollinear spin structure, (b) the decomposition of the starting $\mathrm{CuFe}_{2} \mathrm{O}_{4}$ onto several related $\mathrm{Fe}-\mathrm{Cu}-\mathrm{O}$ phases, and (c) the reduction of $\alpha-\mathrm{Fe}_{2} \mathrm{O}_{3}$ to $\mathrm{Fe}_{3} \mathrm{O}_{4}$. (C) 1998 American Institute of Physics. [S0021-8979(98)02514-6]
\end{abstract}

\section{INTRODUCTION}

The $\mathrm{Cu}-\mathrm{Fe}-\mathrm{O}$ system is of long standing interest in solid state physics, mineralogy, ceramics, and metallurgy. By virtue of magnetic and semiconducting properties, copper ferrite $\left(\mathrm{CuFe}_{2} \mathrm{O}_{4}\right)$ and its solid solutions with other ferrites are widely used in the electronic industry. ${ }^{1}$ Copper ferrite has two crystallographic spinel structures: ${ }^{2}$ the high-temperature cubic phase $\left(c-\mathrm{CuFe}_{2} \mathrm{O}_{4}\right)$ with a lattice parameter of 8.380 $\AA$, and the low-temperature tetragonal phase $\left(t-\mathrm{CuFe}_{2} \mathrm{O}_{4}\right)$ with lattice parameters of $a=8.216 \AA$ and $c=8.709 \AA$. The ideal inverse configuration consists of eight divalent $\left(\mathrm{Cu}^{2+}\right)$ ions on the octahedral (B) sites and 16 trivalent $\left(\mathrm{Fe}^{3+}\right)$ ions equally splitting between the tetrahedral (A) and B sites per unit cell. It is ferrimagnetic at room temperature with Néel temperature of $780(20) \mathrm{K}^{3}$, although lower values down to $710 \mathrm{~K}$ have also been reported. ${ }^{4}$ The magnetization of the A sublattice is antiparallel to that of the B sublattice, whereas magnetic moments of the ions on the A and B sublattices are ferromagnetically ordered. The total magnetic moment of $\mathrm{CuFe}_{2} \mathrm{O}_{4}$ is entirely due to the uncompensated magnetic moments of the eight $\mathrm{Cu}^{2+}$ ions on $\mathrm{B}$ sites. The magnetic moment per unit cell is $\mu=8 \times 1 \mu_{\mathrm{B}}=8 \mu_{\mathrm{B}}$, assuming that each $\mathrm{Cu}^{2+}$ ion contributes one $\mu_{\mathrm{B}}$, where $\mu_{\mathrm{B}}$ is the Bohr magneton. Due to a relatively small energy difference between $\mathrm{Cu}^{2+}$ ions in the A and B sites, ${ }^{5}$ cation redistribution is possible and strongly dependent upon the annealing temperature and cooling rate. Replacing one A-site $\mathrm{Fe}^{3+}$ ion with a B-site

a) Author to whom correspondence should be addressed; electronic mail: jiang@fysik.dtu.dk
$\mathrm{Cu}^{2+}$ ion and vice versa, results in a magnetic moment $\mu$ $=7 \times 1 \mu_{\mathrm{B}}+2 \times 5 \mu_{\mathrm{B}} 1-\mu_{\mathrm{B}}=16 \mu_{\mathrm{B}}$, assuming that each $\mathrm{Fe}^{3+}$ ion contributes five $\mu_{\mathrm{B}}$ and a Néel-type collinear spin structure. Thus a single $\mathrm{Cu}^{2+}$ ion per unit cell on an A site doubles the magnetic moment. However, it has been found that using the thermal quench method, ${ }^{6}$ the magnetic moment of $\mathrm{CuFe}_{2} \mathrm{O}_{4}$ cannot be increased much beyond $16 \mu_{\mathrm{B}}$ per unit cell, since the activation energy of the process increases with the presence of one $\mathrm{Cu}^{2+}$ ion on an A site, thus making the transfer of a second $\mathrm{Cu}^{2+}$ ion very unlikely.

Recently, it has been demonstrated in a variety of intermetallic compounds by Bakker and co-workers ${ }^{7}$ that mechanical milling can efficiently induce different kinds of atomic disorder, such as antisite or triple-defect disorder, i.e., atoms sitting on the "wrong" sublattice with or without simultaneous formation of vacancies, respectively. In zinc ferrite, $\mathrm{ZnFe}_{2} \mathrm{O}_{4}$, a cation redistribution $\left(\mathrm{Zn}^{2+}\right.$ and $\left.\mathrm{Fe}^{3+}\right)$ in A and $\mathrm{B}$ sites has also been reported during mechanical milling in Refs. 8-10. Thus, an attempt was made, i.e., to prepare $\mathrm{CuFe}_{2} \mathrm{O}_{4}$ ferrites with high magnetic moments per unit cell using high-energy mechanical milling. In this work, we present a detailed study of the phase evolution of $\mathrm{CuFe}_{2} \mathrm{O}_{4}$ during mechanical milling in a closed container by $\mathrm{x}$-ray diffraction and Mössbauer spectroscopy. The magnetic properties of mechanically milled samples are presented and discussed on the basis of the microstructures of the samples. Several interesting features are involved in the present work, e.g., mechanochemical reactions, superparamagnetic effects, unsaturated magnetizations for small magnetic particles in high fields, and spin canting effects. 


\section{EXPERIMENT}

The starting material, $\mathrm{CuFe}_{2} \mathrm{O}_{4}$, was prepared by the ceramic method, mixing stoichiometric amounts of $\alpha-\mathrm{Fe}_{2} \mathrm{O}_{3}$ ( $99.999 \%$ purity) and $\mathrm{CuO}$ (99.999\% purity) powders in an agate mortar and heating at $1223 \mathrm{~K}$ for $20 \mathrm{~h}$ in air. Three cycles of grinding and heating were used to ensure complete reaction. A cooling rate of $2 \mathrm{~K}$ per minute was used in the third cycle. The formation of the copper ferrite was confirmed by $x$-ray diffraction analysis. The milling of the original $\mathrm{CuFe}_{2} \mathrm{O}_{4}$ powders was carried out in a closed container using a planetary ball mill (Fritsch Pulverisette 7) in air, with hardened steel $\left(\mathrm{Fe}_{74} \mathrm{Cr}_{18} \mathrm{Ni}_{8}\right)$ vials and balls. The milling intensity was 950 rotations per minute, and a ball-to-powder weight ratio of 20:1 was chosen. A few drops of acetone were added to the containers to improve particle mobility during milling. The milling process was interrupted after selected times to take out small amounts of powder, which were heated in air at $323 \mathrm{~K}$ until completely dry. Samples of $\mathrm{CuFe}_{2} \mathrm{O}_{4}$ were labeled $\mathrm{S} X$, where each $X$ number refers to the total hours of grinding time. The composition of the samples S18, S38, and S98 was determined by scanning electron microscopy with an energy-dispersive $\mathrm{x}$-ray analysis facility in areas of about $1 \times 1 \mathrm{~mm}^{2}$. It was found that the chromium content in the samples S18, S38, and S98 was approximately $0.3,0.5$, and 1.2 at. \%, respectively, originating from the abrasion of the vials and balls. The acetone contamination in samples is studied by heat treatment at 973 $\mathrm{K}$ for $1 \mathrm{~h}$ in air.

$\mathrm{X}$-ray diffraction measurements were performed using a Philips PW-1140 diffractometer with $\mathrm{Cu} K \alpha$ radiation in the $2 \theta$ range of $10^{\circ}-80^{\circ}$ with a step size of $0.01^{\circ}$. Mössbauer measurements were performed with a conventional constantacceleration spectrometer in transmission geometry with a source of about $50 \mathrm{mCi}{ }^{57} \mathrm{Co}$ in a $\mathrm{Rh}$ matrix at 4.2 and 296 $\mathrm{K}$. An electromagnet was used for room-temperature Mössbauer measurements with an external field. All isomer shifts are given relative to that of $\alpha$-Fe at room temperature. Optimal thickness was calculated to be $18 \mathrm{mg} / \mathrm{cm}^{2}$. Lorentzian line shapes were used to fit the Mössbauer spectra recorded. Magnetization measurements were performed in a vibrating sample magnetometer at 4.2 and $300 \mathrm{~K}$ using a superconducting magnet to produce fields up to $9 \mathrm{~T}$.

\section{RESULTS}

Figure 1 shows the x-ray diffraction patterns of the $\mathrm{CuFe}_{2} \mathrm{O}_{4}$ samples after different milling times. The pattern of the sample S0 was indexed to a single phase of tetragonal $\mathrm{CuFe}_{2} \mathrm{O}_{4}$ spinel with lattice parameters of $a=8.227(2) \AA$ and $c=8.699(2) \AA$. After $3 \mathrm{~h}$ milling, the diffraction peaks of the $\mathrm{CuFe}_{2} \mathrm{O}_{4}$ phase lost intensities and significantly broaden, so that at present, we are unable to distinguish the tetragonal from cubic structures. The structure obtained can only be assigned as a spinel. No other phases were found from the $\mathrm{x}$-ray diffraction pattern. Average grain sizes, $\langle\mathrm{d}\rangle$, for the spinel phase were estimated, in Fig. 2, from the broadening of the strongest diffraction peak (at $2 \theta \approx 36^{\circ}$ ) using the Scherrer method, after subtracting instrumental broadening from the experimental linewidth. After the initial milling

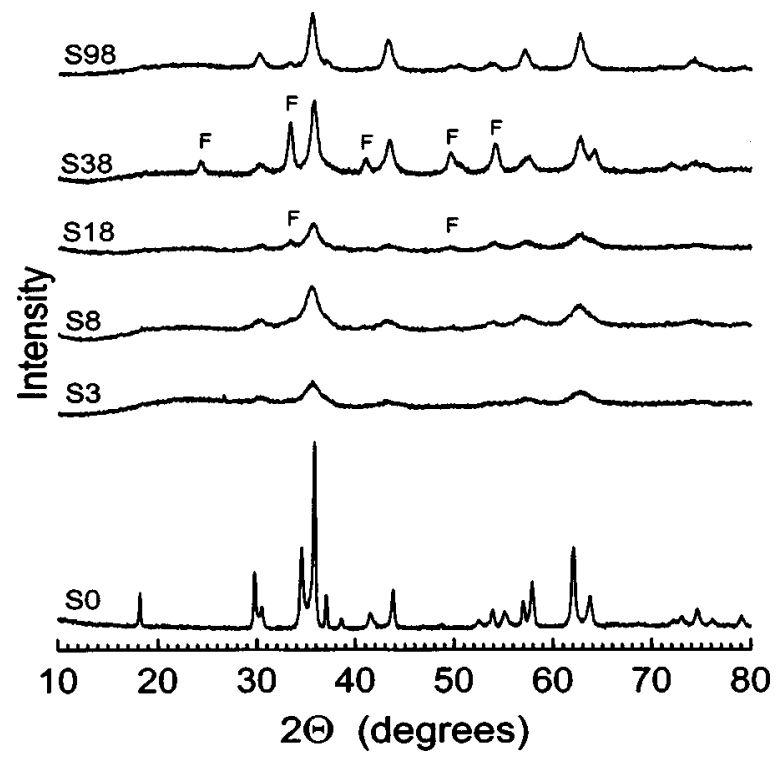

FIG. 1. X-ray diffraction patterns of the $\mathrm{CuFe}_{2} \mathrm{O}_{4}$ samples after different milling times.

process, the average grain size drops from about $200 \mathrm{~nm}$ for the starting powders to $6(2) \mathrm{nm}$ for the sample $\mathrm{S} 3$, and remains essentially unchanged for samples S8 and S18. In addition to the spinel phase two new peaks, marked as F, appear in sample S18. These peaks are further enhanced in the sample $\mathrm{S} 38$, and correspond to $\alpha-\mathrm{Fe}_{2} \mathrm{O}_{3}$. The average grain size of the spinel phase increases to $11(2) \mathrm{nm}$. It should be mentioned that nanometer-sized $\mathrm{CuO}$ and $\mathrm{Cu}$ phases may also exist in the sample S38. These are hardly observable due to broadening and overlapping of Bragg peaks of these phases with the spinel phase. Table I lists $2 \theta$ values of some Bragg peaks for $c-\mathrm{CuFe}_{2} \mathrm{O}_{4}, t-\mathrm{CuFe}_{2} \mathrm{O}_{4}, \mathrm{Fe}_{3} \mathrm{O}_{4}, \alpha-\mathrm{Fe}_{2} \mathrm{O}_{3}$, $\mathrm{CuO}$, and $f c c-\mathrm{Cu}$ powders using $\mathrm{Cu} K \alpha$ radiation at room temperature. ${ }^{11}$ After $98 \mathrm{~h}$ milling, the pattern shows Bragg peaks associated to a spinel phase, while the peaks from the $\alpha-\mathrm{Fe}_{2} \mathrm{O}_{3}$ phase are hardly observable. Meanwhile, the average grain size is found to be about 12(2) nm.

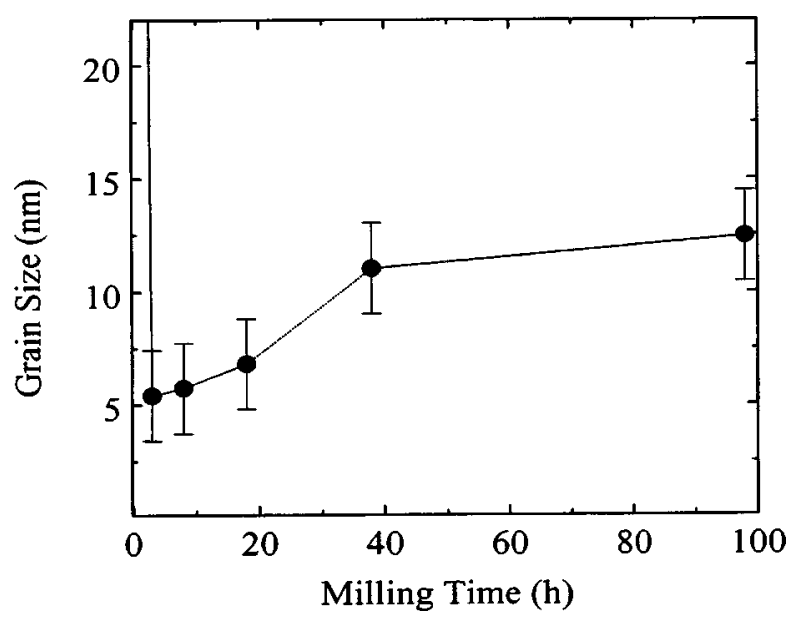

FIG. 2. Average grain sizes vs milling time for the spinel phase estimated from the broadening of the strongest diffraction peak (at $2 \theta \approx 36^{\circ}$ ) using the Scherrer method, after subtracting instrumental broadening from the experimental line width. 
TABLE I. Some $2 \theta$ values and relative intensities of Bragg peaks for the crystalline $c-\mathrm{CuFe}_{2} \mathrm{O}_{4}, t-\mathrm{CuFe}_{2} \mathrm{O}_{4}$, $\mathrm{Fe}_{3} \mathrm{O}_{4}, \alpha-\mathrm{Fe}_{2} \mathrm{O}_{3}$, and $\mathrm{CuO}$, and $f c c-\mathrm{Cu}$ powders using $\mathrm{Cu} K \alpha$ radiation at room temperature. Data taken from Ref. 11.

\begin{tabular}{|c|c|c|c|c|c|c|c|c|c|c|c|}
\hline \multicolumn{2}{|c|}{$c-\mathrm{CuFe}_{2} \mathrm{O}_{4}$} & \multicolumn{2}{|c|}{$t-\mathrm{CuFe}_{2} \mathrm{O}_{4}$} & \multicolumn{2}{|c|}{$\mathrm{Fe}_{3} \mathrm{O}_{4}$} & \multicolumn{2}{|c|}{$\alpha-\mathrm{Fe}_{2} \mathrm{O}_{3}$} & \multicolumn{2}{|c|}{$\mathrm{CuO}$} & \multicolumn{2}{|c|}{$f c c-\mathrm{Cu}$} \\
\hline $2 \theta\left(^{\circ}\right)$ & Int. & $2 \theta\left(^{\circ}\right)$ & Int. & $2 \theta\left(^{\circ}\right)$ & Int. & $2 \theta\left(^{\circ}\right)$ & Int. & $2 \theta\left({ }^{\circ}\right)$ & Int. & $2 \theta\left(^{\circ}\right)$ & Int. \\
\hline 18.5 & 30 & 18.3 & 17 & 18.3 & 8 & 24.1 & 30 & 32.5 & 8 & 43.3 & 100 \\
\hline 30.2 & 50 & 29.9 & 32 & 30.1 & 30 & 33.2 & 100 & 35.4 & 60 & 50.4 & 46 \\
\hline 35.6 & 100 & 30.6 & 13 & 35.4 & 100 & 35.6 & 70 & 35.6 & 100 & 74.1 & 20 \\
\hline 37.2 & 10 & 34.7 & 53 & 37.1 & 8 & 40.9 & 20 & 38.7 & 100 & & \\
\hline 43.0 & 30 & 35.9 & 100 & 43.1 & 20 & 49.5 & 40 & 38.9 & 100 & & \\
\hline 57.1 & 40 & 37.1 & 14 & 53.4 & 10 & 54.1 & 45 & 48.7 & 25 & & \\
\hline 62.8 & 60 & 41.8 & 11 & 56.9 & 30 & 57.6 & 10 & 58.3 & 12 & & \\
\hline 74.5 & 20 & 43.8 & 22 & 62.5 & 40 & 62.5 & 30 & 61.5 & 16 & & \\
\hline \multirow[t]{5}{*}{79.5} & 10 & 53.9 & 10 & 73.9 & 10 & 64.0 & 30 & 65.8 & 12 & & \\
\hline & & 55.5 & 12 & & & 71.9 & 10 & 66.3 & 14 & & \\
\hline & & 57.8 & 24 & & & 75.4 & 8 & 67.9 & 9 & & \\
\hline & & 62.2 & 40 & & & & & 68.1 & 14 & & \\
\hline & & 63.6 & 16 & & & & & & & & \\
\hline
\end{tabular}

In order to gain more information regarding the complicated phase evolution of $\mathrm{CuFe}_{2} \mathrm{O}_{4}$ during milling, Mössbauer measurements at 4.2 and $296 \mathrm{~K}$ have been carried out for the samples with various milling times, as shown in Fig. 3. Mössbauer parameters obtained by fitting the spectra at 4.2 and $296 \mathrm{~K}$ are listed in Tables II and III. For the starting sample S0, two magnetic sextets are observed at both temperatures, which are identical to those of $\mathrm{Fe}^{3+}$ ions in tetrahedral $(B=50.5 \mathrm{~T}$ at $4.2 \mathrm{~K})$ and octahedral $(B=53.7 \mathrm{~T}$ at 4.2 $\mathrm{K}$ ) sites of the $\mathrm{CuFe}_{2} \mathrm{O}_{4}$ spinel. ${ }^{3}$ After $3 \mathrm{~h}$, the sextets almost collapse at $296 \mathrm{~K}$ and a central doublet with broad lines appears. The spectrum can be fitted using two doublets and a tiny broadened sextet with an average hyperfine field of 43.6 $\mathrm{T}$. The isomer shifts for the three subspectra infer that only $\mathrm{Fe}^{3+}$ ions exist in the sample. At $4.2 \mathrm{~K}$, the $\mathrm{S} 3$ sample spectrum consists of an asymmetrically broadened sextet, inferring many iron ions with different hyperfine fields, while the central doublet disappears. For simplicity, only three sextets were used to fit the spectra recorded at $4.2 \mathrm{~K}$ for samples S3, S8, S18, S38, and S98. Due to small grain sizes in the
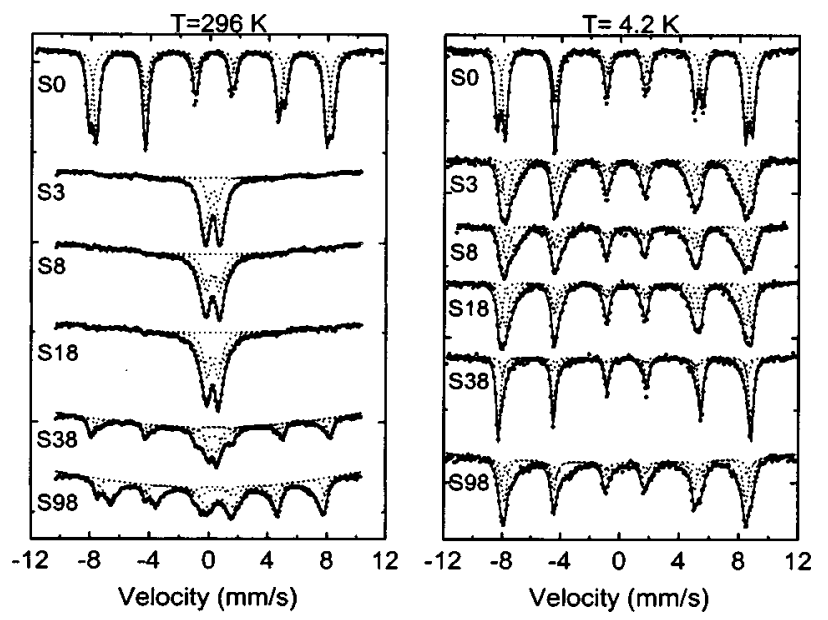

FIG. 3. Mössbauer spectra recorded at 4.2 and $296 \mathrm{~K}$ for the $\mathrm{CuFe}_{2} \mathrm{O}_{4}$ samples with various milling times. sample S3, superparamagnetic relaxation effects could explain the formation of the central doublet at $296 \mathrm{~K}$ and a magnetically split sextet at $4.2 \mathrm{~K}$. To test this hypothesis for ferrimagnetic powders, there are usually two methods: (1) to

TABLE II. Mössbauer parameters: hyperfine field $(B)$, isomer shift $(\delta)$, quadrupole splitting $(\Delta)$, line width $(\Gamma)$, and relative area $(I)$, obtained by fitting the spectra at $4.2 \mathrm{~K}$ for the $\mathrm{CuFe}_{2} \mathrm{O}_{4}$ samples milled for various times.

\begin{tabular}{|c|c|c|c|c|}
\hline $\begin{array}{c}\text { Time } \\
\text { (h) }\end{array}$ & Parameter & H-1 & $\mathrm{H}-2$ & $\mathrm{H}-3$ \\
\hline \multirow{5}{*}{0} & $B(\mathrm{~T})$ & $53.7(1)$ & $50.5(1)$ & \multirow[t]{5}{*}{$\cdots$} \\
\hline & $\delta(\mathrm{mm} / \mathrm{s})$ & $0.48(1)$ & $0.38(1)$ & \\
\hline & $\Delta(\mathrm{mm} / \mathrm{s})$ & $-0.31(1)$ & $-0.02(1)$ & \\
\hline & $\Gamma(\mathrm{mm} / \mathrm{s})$ & $0.43(1)$ & $0.42(1)$ & \\
\hline & $I(\%)$ & $47(2)$ & $53(2)$ & \\
\hline \multirow{5}{*}{3} & $B(\mathrm{~T})$ & $52.8(1)$ & $50.1(1)$ & 46.1(3) \\
\hline & $\delta(\mathrm{mm} / \mathrm{s})$ & $0.49(1)$ & $0.43(1)$ & $0.43(1)$ \\
\hline & $\Delta(\mathrm{mm} / \mathrm{s})$ & $-0.07(1)$ & $-0.01(1)$ & $-0.08(1)$ \\
\hline & $\Gamma(\mathrm{mm} / \mathrm{s})$ & $0.45(3)$ & $0.60(3)$ & $0.80(3)$ \\
\hline & $I(\%)$ & $25(4)$ & $45(4)$ & $31(4)$ \\
\hline \multirow{3}{*}{8} & $B(\mathrm{~T})$ & $52.7(1)$ & $50.2(1)$ & $46.3(3)$ \\
\hline & $\delta(\mathrm{mm} / \mathrm{s})$ & $0.49(1)$ & $0.43(1)$ & $0.45(1)$ \\
\hline & $\Delta(\mathrm{mm} / \mathrm{s})$ & $-0.03(1)$ & $-0.03(1)$ & $-0.03(1)$ \\
\hline \multirow{7}{*}{18} & $\Gamma(\mathrm{mm} / \mathrm{s})$ & $0.49(4)$ & $0.52(1)$ & $0.83(6)$ \\
\hline & $I(\%)$ & $30(4)$ & $35(4)$ & $35(4)$ \\
\hline & $B(\mathrm{~T})$ & $52.9(1)$ & $50.6(1)$ & $46.9(2)$ \\
\hline & $\delta(\mathrm{mm} / \mathrm{s})$ & $0.49(1)$ & $0.44(1)$ & $0.42(1)$ \\
\hline & $\Delta(\mathrm{mm} / \mathrm{s})$ & $-0.01(1)$ & $-0.06(1)$ & $-0.15(2)$ \\
\hline & $\Gamma(\mathrm{mm} / \mathrm{s})$ & $0.41(3)$ & $0.55(4)$ & $0.80(7)$ \\
\hline & $I(\%)$ & $32(3)$ & $41(3)$ & $27(4)$ \\
\hline \multirow{5}{*}{38} & $B(\mathrm{~T})$ & $53.1(1)$ & $51.5(1)$ & $49.5(1)$ \\
\hline & $\delta(\mathrm{mm} / \mathrm{s})$ & $0.49(1)$ & $0.40(1)$ & $0.52(1)$ \\
\hline & $\Delta(\mathrm{mm} / \mathrm{s})$ & $-0.21(1)$ & $0.00(1)$ & $-0.32(5)$ \\
\hline & $\Gamma(\mathrm{mm} / \mathrm{s})$ & $0.32(2)$ & $0.35(6)$ & $0.78(9)$ \\
\hline & $I(\%)$ & $60(5)$ & $17(5)$ & $23(5)$ \\
\hline \multirow{5}{*}{98} & $B(\mathrm{~T})$ & $52.8(1)$ & $50.8(1)$ & $48.0(1)$ \\
\hline & $\delta(\mathrm{mm} / \mathrm{s})$ & $0.56(1)$ & $0.42(1)$ & $0.73(3)$ \\
\hline & $\Delta(\mathrm{mm} / \mathrm{s})$ & $-0.16(2)$ & $0.02(1)$ & $-0.31(4)$ \\
\hline & $\Gamma(\mathrm{mm} / \mathrm{s})$ & $0.49(4)$ & $0.43(3)$ & $1.10(9)$ \\
\hline & $I(\%)$ & $26(4)$ & $35(4)$ & $39(5)$ \\
\hline
\end{tabular}


TABLE III. Mössbauer parameters: hyperfine field $(B)$, isomer shift $(\delta)$, quadrupole splitting $(\Delta)$, line width $(\Gamma)$, and relative area $(I)$, obtained by fitting the spectra at $296 \mathrm{~K}$ for the $\mathrm{CuFe}_{2} \mathrm{O}_{4}$ samples milled for various times. The mark, $\mathrm{F}$, means that linewidths used were fixed in the $\mathrm{CuFe}_{2} \mathrm{O}_{4}$ samples milled for 8 and $18 \mathrm{~h}$.

\begin{tabular}{|c|c|c|c|c|c|}
\hline $\begin{array}{l}\text { Time } \\
\text { (h) }\end{array}$ & Parameter & $\mathrm{H}-1$ & $\mathrm{H}-2$ & P-1 & P-2 \\
\hline \multirow{3}{*}{0} & $B(\mathrm{~T})$ & $51.0(1)$ & $48.3(1)$ & $\ldots$ & $\ldots$ \\
\hline & $\delta(\mathrm{mm} / \mathrm{s})$ & $0.36(1)$ & $0.26(1)$ & & \\
\hline & $\Delta(\mathrm{mm} / \mathrm{s})$ & $-0.14(1)$ & $-0.02(1)$ & & \\
\hline \multirow{7}{*}{3} & $\Gamma(\mathrm{mm} / \mathrm{s})$ & $0.45(1)$ & $0.46(1)$ & & \\
\hline & $I(\%)$ & $43(2)$ & $57(2)$ & & \\
\hline & $B(\mathrm{~T})$ & $43.6(9)$ & $\ldots$ & & \\
\hline & $\delta(\mathrm{mm} / \mathrm{s})$ & $0.45(4)$ & & $0.34(1)$ & $0.33(1)$ \\
\hline & $\Delta(\mathrm{mm} / \mathrm{s})$ & $-0.14(2)$ & & $0.72(3)$ & $1.20(8)$ \\
\hline & $\Gamma(\mathrm{mm} / \mathrm{s})$ & $0.94(6)$ & & $0.44(5)$ & $0.75(6)$ \\
\hline & $I(\%)$ & $8(2)$ & & $21(4)$ & $71(4)$ \\
\hline \multirow{3}{*}{8} & $B(\mathrm{~T})$ & $47.6(9)$ & $\ldots$ & & \\
\hline & $\delta(\mathrm{mm} / \mathrm{s})$ & $0.54(5)$ & & $0.34(1)$ & $0.32(1)$ \\
\hline & $\Delta(\mathrm{mm} / \mathrm{s})$ & $0.27(9)$ & & $0.88(3)$ & $1.30(9)$ \\
\hline \multirow{7}{*}{18} & $\Gamma(\mathrm{mm} / \mathrm{s})$ & $0.90(\mathrm{~F})$ & & $0.61(7)$ & $1.10(9)$ \\
\hline & $I(\%)$ & $3(1)$ & & $42(9)$ & $55(9)$ \\
\hline & $B(\mathrm{~T})$ & $49.5(9)$ & $\cdots$ & & \\
\hline & $\delta(\mathrm{mm} / \mathrm{s})$ & $0.49(7)$ & & $0.35(1)$ & $0.32(1)$ \\
\hline & $\Delta(\mathrm{mm} / \mathrm{s})$ & $0.12(9)$ & & $0.77(3)$ & $1.21(9)$ \\
\hline & $\Gamma(\mathrm{mm} / \mathrm{s})$ & $0.90(\mathrm{~F})$ & & $0.59(7)$ & $1.12(9)$ \\
\hline & $I(\%)$ & $4(1)$ & & $42(9)$ & $53(9)$ \\
\hline \multirow{3}{*}{38} & $B(\mathrm{~T})$ & $50.1(1)$ & $46.9(2)$ & & \\
\hline & $\delta(\mathrm{mm} / \mathrm{s})$ & $0.37(1)$ & $0.42(1)$ & $0.40(1)$ & $0.37(1)$ \\
\hline & $\Delta(\mathrm{mm} / \mathrm{s})$ & $-0.11(1)$ & $-0.10(2)$ & $0.56(2)$ & $1.40(2)$ \\
\hline \multirow{7}{*}{98} & $\Gamma(\mathrm{mm} / \mathrm{s})$ & $0.40(3)$ & $0.78(3)$ & $0.58(5)$ & $1.22(9)$ \\
\hline & $I(\%)$ & $26(3)$ & $25(4)$ & $24(4)$ & $26(4)$ \\
\hline & $B(\mathrm{~T})$ & $47.8(1)$ & $43.9(1)$ & & \\
\hline & $\delta(\mathrm{mm} / \mathrm{s})$ & $0.29(1)$ & $0.60(1)$ & $0.85(1)$ & $0.73(3)$ \\
\hline & $\Delta(\mathrm{mm} / \mathrm{s})$ & $-0.02(1)$ & $-0.04(1)$ & $1.70(3)$ & $-0.31(4)$ \\
\hline & $\Gamma(\mathrm{mm} / \mathrm{s})$ & $0.41(2)$ & $0.96(3)$ & $1.23(8)$ & $1.10(9)$ \\
\hline & $I(\%)$ & $16(2)$ & $57(3)$ & $26(1)$ & $39(5)$ \\
\hline
\end{tabular}

restore a magnetically split sextet in the Mössbauer spectrum by applying an external field; and (2) to determine the magnetic transition temperature of the powder sample or to determine the magnetic state of the powder sample by measuring the saturation magnetization at the temperature, at which the superparamagnetic relaxation occurs. In the former case, when magnetic sextets are restored, then particles must be in a superparamagnetic state at the temperature studied within the Mössbauer measuring time scale $\left(\approx 5 \times 10^{-9} \mathrm{~s}\right)$. In the latter case, when the magnetic transition temperature of the powder sample is found to be higher than the temperature studied, powders should be in a superparamagnetic state. Figure 4 shows a room-temperature Mössbauer spectrum of the sample $\mathrm{S} 3$ in an applied magnetic field of $1.2 \mathrm{~T}$ perpendicular to the direction of propagation of the $\gamma$-rays. It is clearly seen that magnetic splitting occurs, indicating the formation of small superparamagnetic $\mathrm{CuFe}_{2} \mathrm{O}_{4}$ particles in the sample S3. This conclusion is also supported by the magnetization measurements of the same sample in Figs. 7 and 8 (given later). However, some large particles having relatively longer relaxation times are still found. Similar recovery of

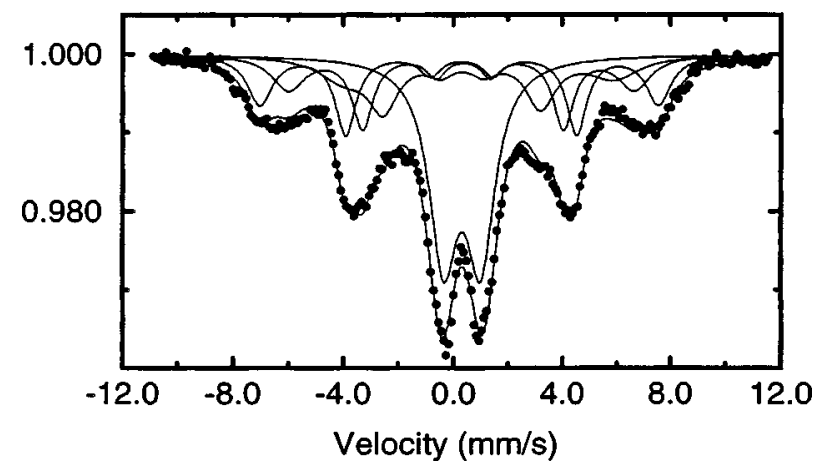

FIG. 4. The room-temperature Mössbauer spectrum of the sample S3 in an applied magnetic field of $1.2 \mathrm{~T}$ perpendicular to the direction of propagation of the $\gamma$-rays. The spectrum was fitted using three sextets and one doublet.

the blocked state is also demonstrated at low temperatures for S3 sample in Fig. 5, where Mössbauer spectra recorded from 80 to $285 \mathrm{~K}$ are shown. The blocking temperature, defined as the temperature where the spectrum is composed by equal magnetic and nonmagnetic areas, was estimated to be approximately $260 \mathrm{~K}$ for this sample. Upon increasing the milling time, the spectra recorded at 4.2 and $296 \mathrm{~K}$ for S8 are similar to those of S3. After $18 \mathrm{~h}$, the resonant lines in the spectrum recorded at $4.2 \mathrm{~K}$ become narrower while the central doublet recorded at $296 \mathrm{~K}$ is asymmetric. (Note that small superparamagnetic $\alpha-\mathrm{Fe}_{2} \mathrm{O}_{3}$ particle shows also an

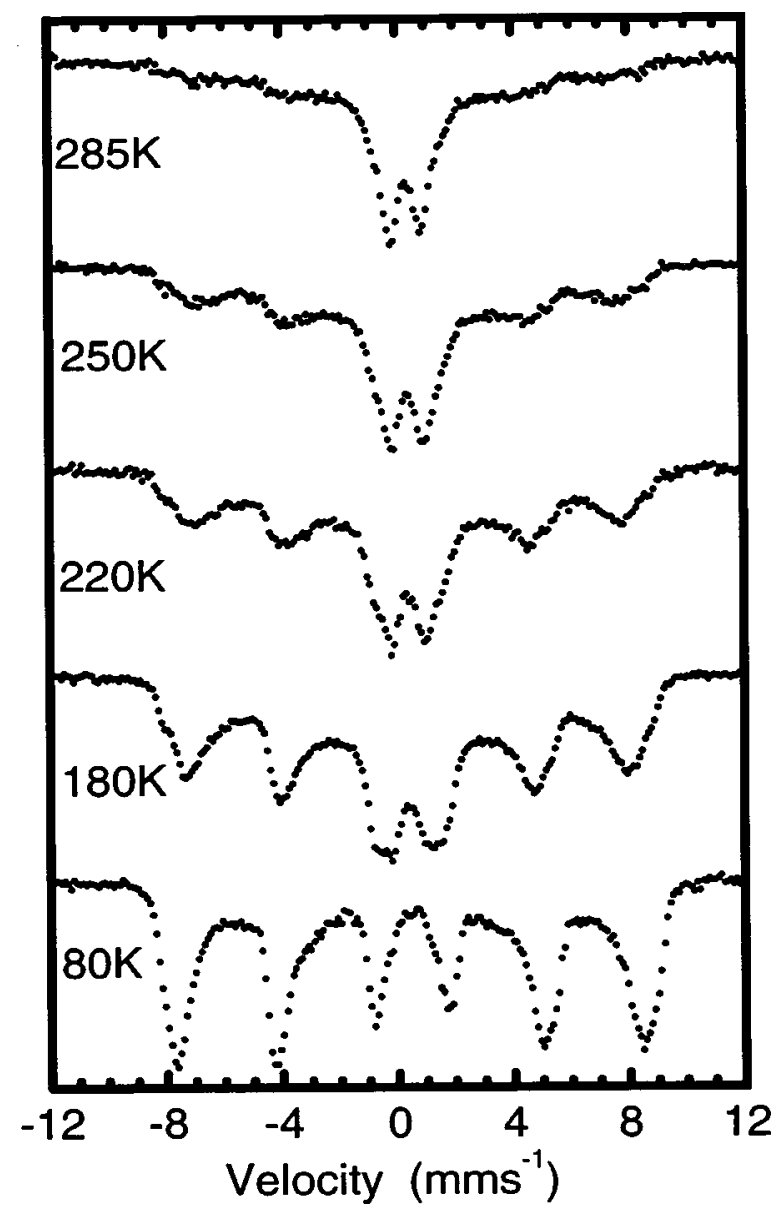

FIG. 5. Mössbauer spectra of the sample milled $3 \mathrm{~h}$ between 80 and $285 \mathrm{~K}$. 


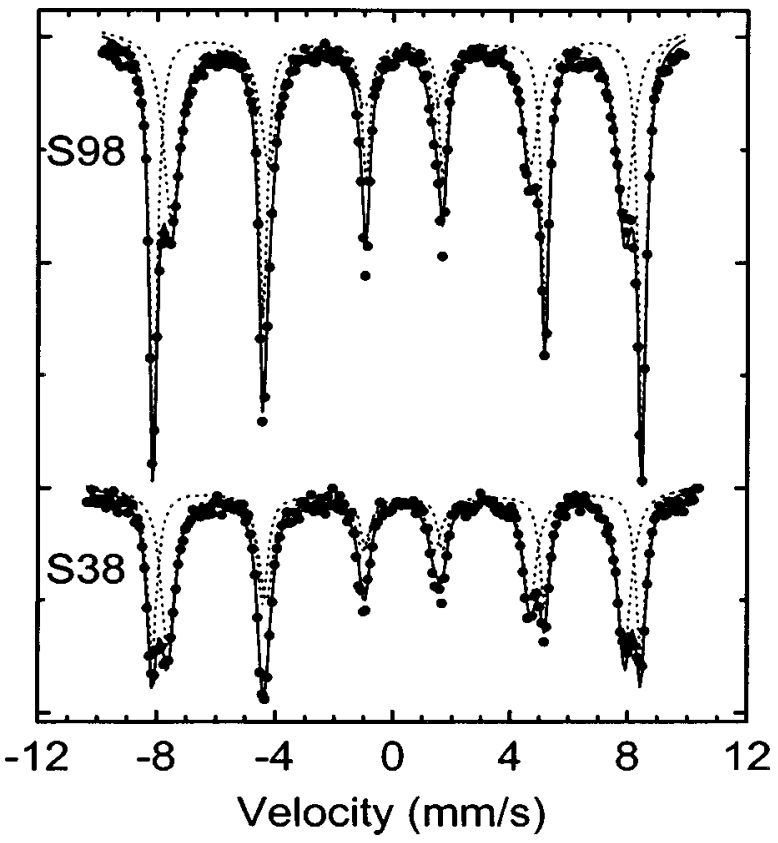

FIG. 6. Room-temperature Mössbauer spectra of samples S38 and S98 annealed at $973 \mathrm{~K}$ for $1 \mathrm{~h}$. Dashed lines correspond to the components to the total fitted spectra, shown as a solid line.

asymmetric doublet. ${ }^{12}$ ) A significant change was observed in the sample milled for $38 \mathrm{~h}$. The spectrum recorded at $296 \mathrm{~K}$ consists of an asymmetrically broadened sextet as well as one central asymmetric doublet, and in the spectrum recorded at $4.2 \mathrm{~K}$ the resonant lines become much narrower

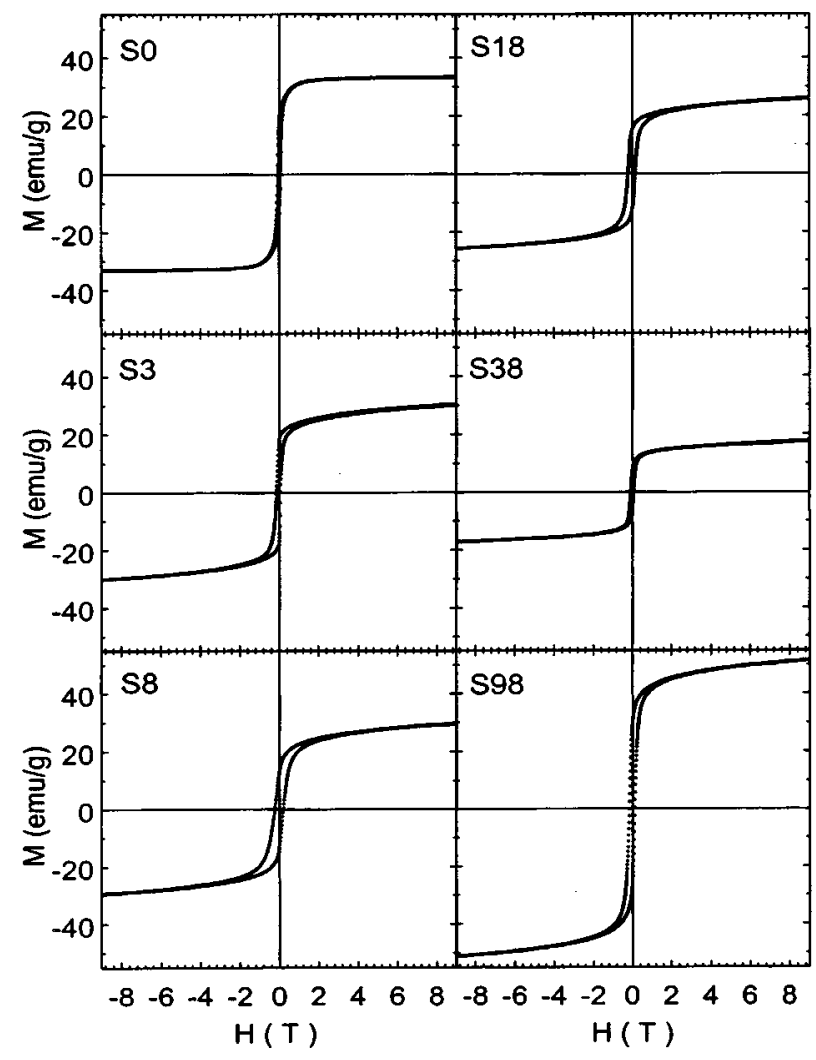

FIG. 7. Magnetization hysteresis curves measured at $4.2 \mathrm{~K}$ for the $\mathrm{CuFe}_{2} \mathrm{O}_{4}$ samples milled for various times.

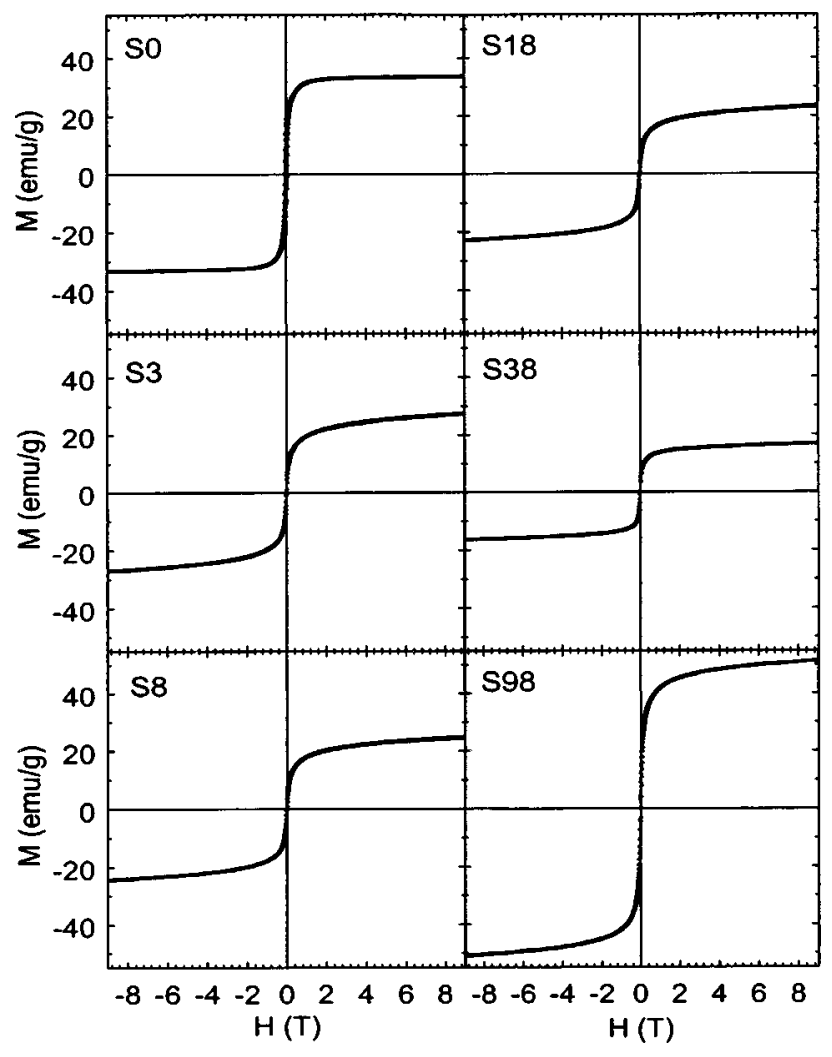

FIG. 8. Magnetization hysteresis curves measured at $300 \mathrm{~K}$ for the $\mathrm{CuFe}_{2} \mathrm{O}_{4}$ samples milled for various times.

compared to those in samples with a milling time less than $38 \mathrm{~h}$. The increase of iron ions in the magnetic sextet at 296 $\mathrm{K}$ could be correlated with the increase of the average grain size in the sample. After $98 \mathrm{~h}$, two broad sextets and one broad doublet could be distinguished in the roomtemperature Mössbauer spectrum, characteristic of the $\mathrm{Fe}_{3} \mathrm{O}_{4}$ spinel phase with defects in the structure. ${ }^{13-15}$ At $4.2 \mathrm{~K}$, the spectrum could be fitted using three sextets. No doublet was observed in all samples studied at $4.2 \mathrm{~K}$.

In order to check the presence of acetone contamination after milling, we heated S38 and S98 samples in air at $973 \mathrm{~K}$ for $1 \mathrm{~h}$. The room-temperature Mössbauer spectra for the annealed samples are shown in Fig. 6. No evidence of other signals except $\alpha-\mathrm{Fe}_{2} \mathrm{O}_{3}$ and $\mathrm{CuFe}_{2} \mathrm{O}_{4}$ was found, within experimental uncertainty. Although samples were heated below the tetragonal-to-cubic transition temperature, and cooled slowly $(2 \mathrm{~K} / \mathrm{min})$, for both samples the resulting hyperfine parameters of $\mathrm{CuFe}_{2} \mathrm{O}_{4}$ correspond to the cubic phase. ${ }^{3} \mathrm{We}$ thus associate this structural change in symmetry with the milling process. No carbides were found by Mössbauer spectroscopy measurements, indicating that acetone did not strongly interact with the powders studied.

Figures 7 and 8 show magnetization hysteresis curves measured at 4.2 and $300 \mathrm{~K}$ for $\mathrm{CuFe}_{2} \mathrm{O}_{4}$ samples milled for various times, respectively. Table IV lists the saturation magnetization, the coercive force, and the ratio of remanent induction to saturation magnetization at 4.2 and $300 \mathrm{~K}$ for all samples. It is clearly seen that the saturation magnetization depends strongly on the milling time. In the initial milling process, the magnetization at $4.2 \mathrm{~K}$ reduces from $33.4 \mathrm{emu} / \mathrm{g}$ 
TABLE IV. Magnetizations at a field of $9 \mathrm{~T}\left(M_{s}\right)$, coercive forces $\left(H_{c}\right)$, and ratios of remanent induction to saturation magnetization $\left(M_{r} / M_{s}\right)$, at 4.2 and $300 \mathrm{~K}$ for the $\mathrm{CuFe}_{2} \mathrm{O}_{4}$ samples milled for various times.

\begin{tabular}{cccccccc}
\hline \hline & & $\mathrm{S} 0$ & $\mathrm{~S} 3$ & $\mathrm{~S} 8$ & $\mathrm{~S} 18$ & $\mathrm{~S} 38$ & $\mathrm{~S} 98$ \\
\hline $4.2 \mathrm{~K}$ & $\begin{array}{l}M_{s} \\
(\mathrm{emu} / \mathrm{g})\end{array}$ & 33.4 & 30.3 & 29.5 & 25.9 & 17.5 & 51.5 \\
& $\begin{array}{l}H_{c} \\
(\mathrm{mT})\end{array}$ & 71 & 129 & 221 & 209 & 82 & 155 \\
& $\begin{array}{l}M_{r} / M_{s} \\
300 \mathrm{~K}\end{array}$ & 0.49 & 0.56 & 0.45 & 0.52 & 0.37 & 0.54 \\
& $\begin{array}{l}M_{s} \\
(\mathrm{emu} / \mathrm{g})\end{array}$ & 33.3 & 27.1 & 24.3 & 23.1 & 16.6 & 51.1 \\
& $\begin{array}{l}H_{c} \\
(\mathrm{mT})\end{array}$ & 67 & 26 & 23 & 20 & 28 & 39 \\
& $M_{r} / M_{s}$ & 0.48 & 0.15 & 0.13 & 0.13 & 0.22 & 0.21 \\
\hline \hline
\end{tabular}

(S0) to $30.3 \mathrm{emu} / \mathrm{g}$ (S3), and to $29.5 \mathrm{emu} / \mathrm{g}$ (S8). Upon increasing the milling time, the magnetization further decreases from $29.5 \mathrm{emu} / \mathrm{g}$ (S8) to $25.9 \mathrm{emu} / \mathrm{g}$ (S18), and then to $17.5 \mathrm{emu} / \mathrm{g}(\mathrm{S} 38)$. However, it is surprising that after $98 \mathrm{~h}$, the value of magnetization increases to $51.5 \mathrm{emu} / \mathrm{g}$. This value of magnetization would correspond to about $19.4 \mu_{\mathrm{B}}$ per unit cell if the milled sample were $\mathrm{CuFe}_{2} \mathrm{O}_{4}$ after $98 \mathrm{~h}$ milling. A discussion of microstructures in the sample will be given later. A similar feature of the saturation magnetization versus milling time in the milled samples was also observed at $300 \mathrm{~K}$. At $4.2 \mathrm{~K}$, milled samples are blocked having nonzero coercive forces, while at $300 \mathrm{~K}$ the coercive forces for these samples are also nonzero, but much smaller than those at $4.2 \mathrm{~K}$. This result could be explained by the fact that milled samples contain a particle size distribution. Most particles have zero coercive forces in a superparamagnetic state at $300 \mathrm{~K}$ within a time scale of about $100 \mathrm{~s}$ by magnetization measurements, and few particles with larger sizes could be still blocked at $300 \mathrm{~K}$. From Table IV it is seen that the $M_{r} / M_{s}$ ratio drops from about 0.5 for S0 to 0.13 for S18 at room temperature. The lower values of $M_{r} / M_{s}$ in milled samples indicate an appreciable fraction of superparamagnetic particles at this temperature. For S38 and S98, a fraction of particles is in the blocked state leading to an increase of $M_{r} / M_{s}$ to 0.22 , assuming that $M_{r} / M_{s}$ does not depend on the phase composition. The $M_{r} / M_{s}$ values for samples studied at $4.2 \mathrm{~K}$ are found to be about 0.5 , which infers weak interactions between particles with uniaxial anisotropy. In addition, it is found that for milled samples the magnetization still slightly increases after $1 \mathrm{~T}$ and does not become saturated even at a field of $9 \mathrm{~T}$. This is not the case for the starting sample S0.

\section{DISCUSSION}

\section{A. Microstructures in milled $\mathrm{CuFe}_{2} \mathrm{O}_{4}$}

One striking feature observed in the milled $\mathrm{CuFe}_{2} \mathrm{O}_{4}$ samples from the $\mathrm{x}$-ray diffraction measurements is that the sample S38 contains a relatively large amount of $\alpha-\mathrm{Fe}_{2} \mathrm{O}_{3}$ while almost no $\alpha-\mathrm{Fe}_{2} \mathrm{O}_{3}$ exists in the sample S98. This phenomenon indicates that chemical decompositions and reductions might occur. Let us first consider possible mechanisms of the formation of $\alpha-\mathrm{Fe}_{2} \mathrm{O}_{3}$. In fact, $\alpha-\mathrm{Fe}_{2} \mathrm{O}_{3}$ is al- ready observed in the sample S18 and a clear evidence of the phase is found in the sample S38, as marked F in Fig. 1. Although the iron atoms, originating from the abrasion of the vials and balls, could be oxidized during milling process, they cannot be the main contribution for the formation of large amount $\alpha-\mathrm{Fe}_{2} \mathrm{O}_{3}$ in the sample, because iron impurities were found to be only a small amount (less than about 3 at. \%) in the sample. On the other hand, by extrapolating thermodynamic data, ${ }^{16,17}$ it was suggested that bulk $\mathrm{CuFe}_{2} \mathrm{O}_{4}$ could decompose at an estimated temperature of about $873 \mathrm{~K}$ via the possible reaction mechanisms: (1) $\mathrm{CuFe}_{2} \mathrm{O}_{4}$ $=\mathrm{CuO}+\alpha-\mathrm{Fe}_{2} \mathrm{O}_{3}, \quad$ (2) $\quad 8 \mathrm{CuFe}_{2} \mathrm{O}_{4}=4 \mathrm{CuO}+6 \alpha-\mathrm{Fe}_{2} \mathrm{O}_{3}$ $+4 \mathrm{CuFeO}_{2}+\mathrm{O}_{2}$, or (3) $4 \mathrm{CuFe}_{2} \mathrm{O}_{4}=2 \alpha-\mathrm{Fe}_{2} \mathrm{O}_{3}+4 \mathrm{CuFeO}_{2}$ $+\mathrm{O}_{2}$. In the present work, initially, the milling rapidly reduces the grain size of $\mathrm{CuFe}_{2} \mathrm{O}_{4}$ to several nanometers in size. In general, the local temperature at collisions with balls and vial during milling process is assumed to be about 473$573 \mathrm{~K}^{18}$ (Note that the local temperature could be much higher when a combustion reaction occurred in ceramic oxide systems during milling, ${ }^{19}$ but in the present system no combustion reaction was observed.) However, in a variety of systems, it has been reported that high-temperature metastable phases (which are stable above $573 \mathrm{~K}$ ) could be formed during nonequilibrium dynamic milling process. ${ }^{20}$ Hence, due to nanometer-sized grains, high local pressures, and temperatures during collisions with balls and vial, we believe that a decomposition process of $\mathrm{CuFe}_{2} \mathrm{O}_{4}$ might occur in the milling process. The decomposition is observable after $18 \mathrm{~h}$ of milling. If one assumes the decomposition following the reactions (1) or (2), then, molar ratios of $\mathrm{CuO}$ to $\alpha-\mathrm{Fe}_{2} \mathrm{O}_{3}$ phases would be 1 or 0.67 , respectively. However, in the x-ray diffraction pattern of the sample S38, no evidence of a relatively large amount of $\mathrm{CuO}$ was observed. Furthermore, no significant quantities of $\mathrm{CuFeO}_{2}$ were observed in the sample S38. Therefore, the reaction (3) could not be occurring during the milling experiments. By studying the $\mathrm{CuFe}_{2} \mathrm{O}_{4}$ and $\mathrm{Fe}_{3} \mathrm{O}_{4}$ phase diagram, and taking into account the possibility of a reduction process in a closed milling container (this process is confirmed in the sample S98), we propose the fourth reaction mechanism: (4) $\mathrm{CuFe}_{2} \mathrm{O}_{4} \rightarrow \alpha-\mathrm{Fe}_{2} \mathrm{O}_{3}+\mathrm{Cu}_{x} \mathrm{Fe}_{3-x} \mathrm{O}_{4}+y(\mathrm{CuO}+\mathrm{Cu})+\mathrm{O}_{2}$, where $\mathrm{Cu}_{x} \mathrm{Fe}_{3-x} \mathrm{O}_{2}$ is a spinel solid solution with $1>x \geqslant 0$. Assuming $x=0.9$ and $y=1$, the molar ratio of $(\mathrm{CuO}+\mathrm{Cu})$ to $\alpha-\mathrm{Fe}_{2} \mathrm{O}_{3}$ phases is about 0.58 and the individual molar ratios of $\mathrm{CuO}$ to $\alpha-\mathrm{Fe}_{2} \mathrm{O}_{3}$ and of $\mathrm{Cu}$ to $\alpha-\mathrm{Fe}_{2} \mathrm{O}_{3}$ phases could be lower than 0.3 when $50 \%$ of the total $\mathrm{CuO}$ is reduced to $\mathrm{Cu}$. It seems that this decomposition reaction process does not contradict the results obtained from the x-ray diffraction and Mössbauer measurements in the milled $\mathrm{CuFe}_{2} \mathrm{O}_{4}$ samples.

From ball milling experiments of pure $\alpha-\mathrm{Fe}_{2} \mathrm{O}_{3}$ (Refs. $13-15,21,22$ ) or a mixture of $\alpha-\mathrm{Fe}_{2} \mathrm{O}_{3}$ and $\mathrm{SiO}_{2}$ (Ref. 23) in air, it was demonstrated that a reduction of $\alpha-\mathrm{Fe}_{2} \mathrm{O}_{3}$ to $\mathrm{Fe}_{3} \mathrm{O}_{4}$ could occur in a closed container after prolonged milling. For the reduction process many mechanisms have been proposed $^{13,14,21,22,24}$ and were recently discussed in Ref. 13 . It was suggested that bond breaking followed by the release of oxygen from the vial is the dominant process for the reduction reaction while the contribution from the contamination, originating from the abrasion of the vial and balls, is 
insignificant. This reduction process is also found in the sample $\mathrm{S} 98$, where almost all $\alpha-\mathrm{Fe}_{2} \mathrm{O}_{3}$ are reduced to the spinel $\mathrm{Fe}_{3} \mathrm{O}_{4}$ phase. It should be noted that due to the line broadening and the similar lattice constants it is impossible, from $\mathrm{x}$-ray diffraction measurements, to distinguish the $\mathrm{CuFe}_{2} \mathrm{O}_{4}, \mathrm{Cu}_{x} \mathrm{Fe}_{3-x} \mathrm{O}_{4}$, from $\mathrm{Fe}_{3} \mathrm{O}_{4}$ phases. The formation of spinel $\mathrm{Fe}_{3} \mathrm{O}_{4}$ phase in the sample $\mathrm{S} 98$ is directly confirmed by the room-temperature Mössbauer spectrum in Fig. 3, and indirectly confirmed in the annealed samples in Fig. 5. Therefore, the sample S98 may consist mainly of a mixture of spinel $\mathrm{Fe}_{3} \mathrm{O}_{4}$ and $\mathrm{Cu}_{x} \mathrm{Fe}_{3-x} \mathrm{O}_{4}$ phases. The reduction process could also occur in the sample $\mathrm{S} 38$, where $\mathrm{CuO}$ is initially reduced to $\mathrm{Cu}$ because this reduction is relatively easy compared to the reduction of $\alpha-\mathrm{Fe}_{2} \mathrm{O}_{3}$ (Ref. 25).

\section{B. Magnetic behavior in milled $\mathrm{CuFe}_{2} \mathrm{O}_{4}$}

In general, atomic disorders (e.g., a cation redistribution between $\mathrm{A}$ and $\mathrm{B}$ sites in spinel ferrites) could result in a change of the lattice parameter due to atomic size mismatch. Unfortunately, in ball milled samples S3 and S8, the precise determination of lattice parameters is impossible because of the peak broadening. Thus, the degree of inversion in the samples cannot be deduced from the x-ray diffraction measurements. The cation redistribution phenomenon in ferrites has often been studied using Mössbauer spectroscopy, in which the resonant areas of subspectra of iron ions in A and $\mathrm{B}$ sites is proportional to the cation population at both sites, assuming the equal recoilless fraction in A and B sites. The resonant area ratio (RAR) of $B$ to $A$ should be larger than one for $\mathrm{CuFe}_{2} \mathrm{O}_{4}$ spinel ferrites. In the sample S0, the RAR value determined at $4.2 \mathrm{~K}$ was found to be only 0.9 . This could be due to an overlap of A and B subspectra following an overestimation of the area of the subspectrum A, which has also been reported by Evans and Hafner. ${ }^{3}$ To interpret the Mössbauer spectra the superexchange interaction via oxygen ions must be considered. The strength of the interaction decreases as the distance between the magnetic ions increases, and also as the angle of the $\mathrm{Fe}^{3+}-\mathrm{O}^{2}-\mathrm{Fe}^{3+}$ bonds decreases from $180^{\circ}$ to $90^{\circ}$. Accordingly, it has been known that the $\mathrm{Fe}^{3+}(\mathrm{A})-\mathrm{O}^{2}-\mathrm{Fe}^{3+}(\mathrm{B})$, the $\mathrm{A}-\mathrm{B}$ interaction, is antiferromagnetic and much stronger than the ferromagnetic $\mathrm{A}-\mathrm{A}$ and $\mathrm{B}-\mathrm{B}$ interactions between iron ions or between iron and copper ions. ${ }^{26,27}$ In $\mathrm{CuFe}_{2} \mathrm{O}_{4}$, each iron ion at an $\mathrm{A}$ site is surrounded by twelve octahedral ions. It is likely that the replacement of one $\mathrm{Fe}^{3+}$ ion by a $\mathrm{Cu}^{2+}$ ion at $\mathrm{B}$ site does not produce a large enough change in the total superexchange interaction to cause a considerable difference in the hyperfine field. On the other hand, each iron ion at a B site has only six $\mathrm{A}$ nearest neighbors. If one $\mathrm{Fe}^{3+}$ ion at an $\mathrm{A}$ site is replaced by $\mathrm{Cu}^{2+}$ ion, the superexchange interaction will be altered by an appreciable amount. This will result in a line broadening of the subspectrum of iron ions at the B sites because $\mathrm{Fe}^{3+}$ (B) ions with different environments on the A sublattice have different hyperfine fields. Consequently, the resonant lines in a Mössbauer spectrum will become more broadened due to a hyperfine field distribution of $\mathrm{Fe}^{3+}$ ions at $\mathrm{B}$ sites. This is indeed observed in the samples S3 and S8, indicating that the milling process creates a cation redistri- bution in $\mathrm{CuFe}_{2} \mathrm{O}_{4}$. In addition, the broad doublet at $296 \mathrm{~K}$ can be fitted with two doublets with quadrupole splittings of about 0.72 and $1.20 \mathrm{~mm} / \mathrm{s}$. In general, the octahedral site has trigonal point symmetry and one anticipates a large electric field gradient. ${ }^{28}$ Qualitatively, the area ratio of the two doublets listed in Table II also indicates a cation redistribution between A and B sites in the milled sample. It is, however, difficult to accurately analyze the RAR value because of the large overlap between A and B subspectra and the possible presence of vacancies in the milled samples. A quantitative analysis has therefore not been done.

It has been mentioned that $\mathrm{CuFe}_{2} \mathrm{O}_{4}$ with high magnetic moments could be prepared by cation redistribution. But, the magnetization value for the sample S3 is found to be lower than that for So. However, it is obviously seen from the magnetization curve for S3 in Fig. 7 that the magnetization does not saturate at even high field $(9 \mathrm{~T})$. This phenomenon could result from two possible reasons: (1) the existence of spin canting in S3, and/or (2) the formation of an antiferromagnetic $\alpha-\mathrm{Fe}_{2} \mathrm{O}_{3}$ thin surface layer, caused by the initial decomposition of $\mathrm{CuFe}_{2} \mathrm{O}_{4}$. The spin canting effect has been reported in several nanometer-sized ferrites. ${ }^{29} \mathrm{We}$ observed a large degree of spin canting within small $\mathrm{NiFe}_{2} \mathrm{O}_{4}$ particles prepared by mechanical milling, which results in about $30 \%$ reduction of the saturated magnetization. ${ }^{30}$ Spins between inter- and intra-lattices (A and B) could no longer be a Néeltype collinear structure in partially inverted ferrites, due to random superexchange ferromagnetic and antiferromagnetic interactions. Furthermore, the surface structure disorder also contributes to the spin canting. The nature of the spin canting in small magnetic particles is still debated. A similar reduction of the saturation magnetization of milled $\mathrm{NiFe}_{2} \mathrm{O}_{4}$ particles was also reported by Berkowitz and co-workers. ${ }^{31}$ Similarly, in partially inverted $\mathrm{CuFe}_{2} \mathrm{O}_{4}$ samples ( 33 and S8), the reduction of $M_{s}$ could be mainly due to the spin canting effect. After further studying the $M_{s}$ values for the samples S3 and S8, it is found that the second mechanism does not play an important role in the initial milling process because if the mechanism were for the reduction of $M_{s}$ in the sample S3, then a further large reduction would be expected in S8. This is not the case, and a very slight decrease at 4.2 $\mathrm{K}$ was observed from S3 to S8 in Fig. 7. Upon increasing the milling time, the decomposition process accelerated so that the fraction of iron ions in the small antiferromagnetic $\alpha-\mathrm{Fe}_{2} \mathrm{O}_{3}$ particles, which have very low saturation magnetization (less than $1 \mathrm{emu} / \mathrm{g}$ ), ${ }^{32}$ increases. Therefore, the total saturated magnetization of the milled samples decreases with increasing the milling time, as observed in Table IV. Meanwhile, the decomposition of $\mathrm{CuFe}_{2} \mathrm{O}_{4}$ also causes the narrowing of resonant lines in Mössbauer spectra recorded at 4.2 $\mathrm{K}$ from $\mathrm{S} 8$ to $\mathrm{S} 38$ since the hyperfine field of small $\alpha-\mathrm{Fe}_{2} \mathrm{O}_{3}$ particles at $4.2 \mathrm{~K}$ is about $53.5 \mathrm{~T}$ (Refs. 23 and 28) and the number of iron ions having low hyperfine fields decreases. Furthermore, the $M_{s}$ at $4.2 \mathrm{~K}$ for $\mathrm{Fe}_{3} \mathrm{O}_{4}$ is 98 emu/g, ${ }^{33}$ which is much larger than that of $\mathrm{CuFe}_{2} \mathrm{O}_{4}$. This results in an increase of $M_{s}$ for the sample $\mathrm{S} 98$, consisting of a mixture of spinel $\mathrm{Fe}_{3} \mathrm{O}_{4}$ and $\mathrm{Cu}_{x} \mathrm{Fe}_{3-x} \mathrm{O}_{4}$ phases. 


\section{CONCLUSIONS}

We have investigated the phase evolution of $\mathrm{CuFe}_{2} \mathrm{O}_{4}$. during high-energy ball milling in a closed container, using x-ray diffraction, Mössbauer spectroscopy, and magnetization measurements. It was found that ball milling could be used to prepare nanometer-sized $\mathrm{CuFe}_{2} \mathrm{O}_{4}$ particles with a partially inverted spinel structure. The magnetization of the particles does not saturate at a field of $9 \mathrm{~T}$, which could be due to the spin canting effect in the partially inverted $\mathrm{CuFe}_{2} \mathrm{O}_{4}$ samples. The reduction of magnetization observed in these samples also supports this interpretation. Superparamagnetic relaxation effects also occur in the small particles. Upon increasing the milling time, nanometer-sized $\mathrm{CuFe}_{2} \mathrm{O}_{4}$ particles decompose to $\alpha-\mathrm{Fe}_{2} \mathrm{O}_{3}$ and other phases. This reaction results in a further decrease of the magnetization value of milled samples, since small $\alpha-\mathrm{Fe}_{2} \mathrm{O}_{3}$ particles have a very low saturation magnetization value. After a milling time of $98 \mathrm{~h}$, a reduction process from $\alpha-\mathrm{Fe}_{2} \mathrm{O}_{3}$ to $\mathrm{Fe}_{3} \mathrm{O}_{4}$ was observed, with the consequent increase of magnetization due to a high saturation value of $\mathrm{Fe}_{3} \mathrm{O}_{4}$.

\section{ACKNOWLEDGMENTS}

Discussions with S. Mørup and financial support by the FAPESP and the Danish Technical Research Council are gratefully acknowledged.

${ }^{1}$ See for example, Proceedings of the International Symposium on Ferrites in Asia '97, Tokyo, Japan, September, 1997, and Proceedings of the Sixth International Conference on Ferrites, Tokyo, Japan, October, 1992.

${ }^{2}$ S. C. Schaefer, G. L. Hundley, F. E. Block, R. A. McCune, and R. V. Mrazek, Metall. Trans. A 1, 2557 (1970).

${ }^{3}$ B. J. Evans and S. Hafner, J. Phys. Chem. Solids 29, 1573 (1968).

${ }^{4}$ S. Krupicka and P. Novák, "Oxide Spinels" in Ferromagnetic Materials, edited by E. P. Wolfarth (North-Holland, Amsterdam, 1982), Vol. 3.

${ }^{5}$ K. T. Jacob and C. B. Alcock, Metall. Trans. B 6, 215 (1975); J. D. Dunitz and L. E. Orgel, J. Phys. Chem. Solids 3, 318 (1957).

${ }^{6}$ R. A. McCurrie, in Ferromagnetic Materials Structure and Properties (Academic, London, 1994), p. 134.

${ }^{7}$ H. Bakker, G. F. Zhou, and H. Yang, Prog. Mater. Sci. 39, 159 (1995), and references therein.

${ }^{8}$ Y. T. Pavljukhin, Y. Medikov, and V. V. Boldyrev, J. Solid State Chem.
53, 155 (1984); Mater. Res. Bull. 18, 630 (1983); and V. V. Boldyrev, Solid State Ionics 63, 537 (1993), and references therein.

${ }^{9}$ A. Ye. Yermakov, Mater. Sci. Forum 88-90, 577 (1992), and references therein.

${ }^{10}$ K. Tkacova, V. Sepelak, N. Stevulova, and V. V. Boldyrev, J. Solid State Chem. 123, 100 (1996); and V. Sepelek, K. Tkacova, and V. V. Boldyrev, Mater. Sci. Forum 228-231, 783 (1996).

${ }^{11}$ JCPDS cards: $25-283$, 34-425, 19-629, 33-664, 41-254, and 4-836 (International Centre for Diffraction Data, Swarthmore, PA, 1996).

${ }^{12}$ W. Kundig, H. Bömmel, G. Constabaris, and R. H. Lindquist, Phys. Rev. 142, 327 (1966).

${ }^{13}$ S. Linderoth, J. Z. Jiang, and S. Mørup, Mater. Sci. Forum 235-238, 205 (1997).

${ }^{14}$ S. J. Campbell, W. A. Kaczmarek, and G. M. Wang, Nanostruct. Mater. 6, 735 (1995).

${ }^{15}$ P. Matteazzi and G. Le Caer, Mater. Sci. Eng., A 149, 135 (1991).

${ }^{16}$ K. T. Jacob, K. Fitzner, and C. B. Alcock, Metall. Trans. B 8, 451 (1977).

${ }^{17}$ T. Rosenqvist and A. Hofseth, Scand. J. Metall. 9, 129 (1980).

${ }^{18}$ C. C. Koch, Mater. Sci. Eng. 15, 194 (1991).

${ }^{19}$ G. B. Schaffer and P. G. McCormick, Metall. Trans. A 21, 2789 (1990).

${ }^{20}$ See for example, C. C. Koch, in Material Science and Technology, edited by R. W. Cahn, P. Hassen, and E. J. Kramer (VCH, Weinheim, 1991), Vol. 15, p. 193; and W. L. Johnson, Prog. Mater. Sci. 30, 81 (1986).

${ }^{21}$ W. A. Kaczmarek and B. W. Ninham, IEEE Trans. Magn. 30, 732 (1994); W. A. Kaczmarek, I. Onyszkiewicz, and B. W. Ninham, ibid. 30, 4725 (1994).

${ }^{22}$ T. Kosmac and T. H. Courtney, J. Mater. Res. 7, 1519 (1992).

${ }^{23}$ J. Z. Jiang, Y. X. Zhou, S. Mbrup, and C. B. Koch, Nanostruct. Mater. 7, 401 (1996).

${ }^{24}$ S. Begin-Colin, G. Le Caer, M. Zandona, E. Bouzy, and B. Malaman, J. Alloys Compd. 227, 157 (1995).

${ }^{25}$ R. C. Weast, M. J. Astle, and W. H. Beyer, in Handbook of Chemistry and Physics, 64th ed. (CRC, Boca Raton, Florida, 1983-1984), D-51.

${ }^{26}$ A. H. Morrish, in The Physical Principles of Magnetism (Wiley, New York, 1966), p. 503.

${ }^{27}$ J. Smit and H. P. J. Wijn, Ferrites (Philips, The Netherlands, 1959).

${ }^{28}$ N. N. Greenwood and T. C. Gibb, Mössbauer Spectroscopy (Chapman and Hall, London, 1971).

${ }^{29}$ V. A. M. Brabers, in Handbook of Magnetic Materials, edited by K. H. J. Buschow (North-Holland, Amsterdam, 1995), Vol. 8, p. 297.

${ }^{30}$ J. Z. Jiang (unpublished).

${ }^{31}$ A. E. Berkowitz, J. A. Lahut, I. S. Jacobs, L. M. Levinson, and D. W. Forester, Phys. Rev. Lett. 34, 594 (1975); A. E. Berkowitz, J. A. Lahut, and C. E. VanBuren, IEEE Trans. Magn. 16, 184 (1980).

${ }^{32}$ A. H. Morrish, Canted Antiferromagnetism: Hematite (World Scientific, Singapore, 1994).

${ }^{33}$ B. D. Cullity, in Introduction to Magnetic Materials (Addison-Wesley, Reading, MA, 1972), p. 190. 